\title{
PROSPECTS AND CHALLENGES OF ENTREPRENEURSHIP DEVELOPMENT IN THE KURDISTAN REGION OF IRAQ: AN OVERVIEW
}

\author{
Zrar Mohsin Mohammadali \\ Department of Business Administration, Soran Technical Institute, Erbil Polytechnique University, \\ Soran, Kurdistan Region, Iraq \\ zrar.mohammed@epu.edu.iq \\ Sabir Sadiq Abdulkhaliq \\ Department of Business Management, Faulty of Law, Political Science and Management, Soran University, \\ Soran, Kurdistan Region, Iraq \\ sabir.abdulkhaliq@soran.edu.iq
}

\begin{abstract}
Entrepreneurship as a driver of innovation and economic growth plays a key role in economic development and the appearance of knowledge and innovation-based economies. The most important effects of entrepreneurship development are increasing innovation, upgrading technology, increasing employment, producing technical knowledge, and generating income distribution at the community level, which can lead to increased national wealth and economic growth. At the moment, global developments are made entrepreneurship so important, and organizations need more innovation and entrepreneurship than ever before to adapt to new circumstances. In fact, in relation to entrepreneurship as the most important factor in economic development, organizations can gain more market share. The objectives of this study are to examine and overview the prospects and challenges of entrepreneurship in Iraq's Kurdistan region. In this regard, it can be said that with the human resources available and the valuable experiences available in the field of entrepreneurship around the world, it is necessary to plan for entrepreneurship development in the Kurdish Region of Iraq (KRI). It is revealed in this study Iraqi Kurdistan is determined can be one of the top entrepreneurial centers in the region with the scientific ability of specialists, and the potential of human resources, flexible structure and efficient technology. This paper recommended some strategies to reform and removing barriers to entrepreneurship development in the Kurdistan Region of Iraq by using factors such as entrepreneurship development and appropriate culture building, job training, setting up small business development centers, sponsoring entrepreneurs, establishing the legal framework for entrepreneurial activities, and providing spiritual support to entrepreneurs can lead to social, economic and industrial development and the declines of unemployment.
\end{abstract}

KEYWORDS: Entrepreneurship, Development, Prospects, Challenges.

JEL CLASSIFICATION: M13, M38

Received: October 2 $2^{\text {nd }}, 2019$

1st Revision: October 10 $0^{\text {th }}, 2019$

Accepted: November 27 th 2019

DOI: 10.2478/IJEK-2019-0006

Reference: Mohammadali, Z. M., Abdulkhaliq S. S. (2019). PROSPECTS AND CHALLENGES OF ENTREPRENEURSHIP DEVELOPMENT IN THE KURDISTAN REGION OF IRAQ: AN OVERVIEW. International Journal of Entrepreneurial Knowledge, 7(2), 4-16. doi:10.12345-0006

\section{INTRODUCTION}

Entrepreneurship is seen as an engine of economic and industrial development and a driver of private investment and one of the key drivers of countries' sustainable development (Cassim et al., 2014). Nowadays, in an evolving world, where science or technology is influenced by the wills or desires, success is achieved for societies that have skilled, creative and self-confident workforce for the reason 
that, in the creative world, innovators are the source of great developments such as industry, education, and services. Based on the global growth and development process, it can be found that with the growth and development of advanced technologies, the role of entrepreneurs has ever more increased (Jafari-Moghadam et al., 2017). On the other hand, rapid technological changes in recent years have made countries more aware of the importance of innovation and entrepreneurship. In such societies, the impact of entrepreneurship and innovation has been vast, ranging from changes in social values to accelerate economic growth, including employment creation, technology development, recognition and expansion of new markets, organization and effective utilization of resources involves encouraging investment and increasing wealth in society (Dovbiy et al., 2017).

Since the beginning of the 1980s, governments have changed their policy direction to encourage and facilitate entrepreneurship, relying on their government management. In fact, this shift can be seen as a reaction to the evolving economic and social environment of countries facing technological advances, the growth of global competition, the emergence of a knowledge-based economy, economic and industrial restructuring, high levels of value acceptance. Democracy and private sector development have done. Governments have recognized the solution to managing these accelerating changes in entrepreneurship and have taken various steps to promote entrepreneurship (Nkechi et al., 2012). Researchers have made many definitions of entrepreneurship, for example, Mathew (2010), defines entrepreneurship as the risk and responsibility of designing and implementing a business strategy or starting a business. He also uses entrepreneurship as the disruptive force of the economy and calls it creative destruction (Mathew, 2010). In addition, the concept of entrepreneurship can also be interpreted as value creation. In this sense, a person who is empowered to perceive and find vacancies and opportunities and to create value by cultivating his/her idea and transforming it into a new product or service in society is called an entrepreneur (Niyazi, 2008). In other words, entrepreneurs are those who, along with risk-taking, seize opportunities and seek new ways to profit by relying on their ideas and experiences (Rabiei and Nazarian, 2013). In addition, the entrepreneur is someone who, alone or in partnership, initiates or adopts something with creativity and innovation, and by accepting the financial, social, moral and psychological risks, creatively creates new products to market and overcome competitors (Montoro-Sánchez et al., 2011).

\section{ENTREPRENEURIAL BACKGROUNDS AND THEORIES}

Entrepreneurship first came up in economic theories, and economists took a different view of it, and thoroughly outlined entrepreneurial theory. Entrepreneurship is a transnational and socio-economic phenomenon (Samitowska, 2011). Until Joseph Schumpeter introduced entrepreneurship as the engine of economic development. Schumpeter's theories about the pivotal role of entrepreneurship in economics due to neoclassical economic thinking and mass production were ignored until the early 1980s and went to the stage of eliminating economic theories (Drucker, 2012; Muro et al., 2013). Entrepreneurial literature covers various disciplines, most notably: economics, psychology, anthropology, and sociology. In the first place, by examining the economic theories of entrepreneurship, it can be seen that in economic thought, there are no theories and definitions that are accepted by all experts. There are generally two important streams of entrepreneurship theory: 1. Psychological; 2. Sociological (Muro et al., 2013).

Psychological researchers are seeking to identify the psychological characteristics of entrepreneurs. These characteristics are related to entrepreneurial performance. These psychological theories apply a broad view of psychology. Sociological theories are also looking at how the environment affects entrepreneurship (Muro et al., 2013). Some of these environmental factors affecting entrepreneurship in the sociological domain include: 1 . The importance of organizations' investment rates; 2. Political and government policy factors; 3. Culture; 4. Location; 5. Professionalization of entrepreneurship. Joseph Schumpeter states that entrepreneurs are driving the capitalist system's societies and markets. And markets are not related to supply and demand mechanisms, but entrepreneurs are responsible for 
new product design, technological horizons, and lower production costs. Schumpeter uses entrepreneurship in a broad sense, including corporate executives and even public and nonprofit agencies. According to Peter Drucker, who defines entrepreneurs as opportunity seekers, everyone can be an entrepreneur. Drucker believes that we should talk about the actions and behaviors of entrepreneurs, not about the psychology of entrepreneurs (Drucker, 2012).

As the first research in the field of entrepreneurial psychological characteristics, David McClelland studied the motivation for success in 1987, and risk orientation is a behavioral attribute presented by Knight in 1921. Parston defines the entrepreneurial process as a managerial behavior that constantly seizes opportunities to achieve the results of one's capacity. The results of the surveys have provided new insight into the field of entrepreneurship, and to most researchers, entrepreneurship is the engine of economic and social change that can lead to employment, human resource efficiency, and national resurgence (Muro et al., 2013: Drucker, 2012).

\section{THE IMPORTANCE OF ENTREPRENEURSHIP}

Studying entrepreneurship is important for several reasons. Entrepreneurial capabilities first lead to innovation and technical change capabilities, and hence to economic growth. Second, as Austrian economists have argued, entrepreneurship is a process by which supply and demand equals. Third, entrepreneurship is an important process by which new knowledge becomes a commodity and service. Fourth, entrepreneurship has become an important profession and we need to understand its role in the development of human and intelligent capital. Nowadays entrepreneurship is an essential key in the growth and development of countries because it provides numerous job opportunities and offers many products and services (Liñán and Chen, 2009; Wibowo and Saptono, 2018).

The role of entrepreneurship in economic development is not limited to incremental per capita income, but involves the establishment and initiation of structural changes in economic and social activity. This evolution is accompanied by growth and increased returns, which will allow for greater sharing among different participants (Adenuga and Ayodele, 2013). In the global arena, creative and innovative individuals as entrepreneurs have been the source of great developments in the industrial, manufacturing and service sectors and are also referred to as national champions. The importance of entrepreneurship enough that in India over the past twenty years, only five hundred entrepreneurial institutes have been set up and even a number of large companies have turned to entrepreneurs to solve their problems. There is also evidence that entrepreneurship is the cause of the development of industrialized countries such as the US, Japan and Germany. Entrepreneurship has now emerged as a profession and, like other professions, must be developed and nurtured through specific educational and academic programs (Abtahi, et al., 2014).

Entrepreneurship is an important and endless resource of all human societies that derives from human creativity and is both inexpensive and inexhaustible on the one hand (Popescu and Simion, 2012). Entrepreneurship as a symbol of business endeavors and entrepreneurs are pioneers of business success in society. Their ability to seize opportunities, their ability to innovate, and their capacity for success are considered as indicators of new entrepreneurship. Entrepreneurs play an important role in economic growth in terms of leadership, management, innovation, efficiency, job creation, competitiveness, productivity, and startups. Entrepreneurial revolution is needed in societies. In the present century, this revolution is far more important than the industrial revolution to provide space for mass entrepreneurial discussion. The trend towards entrepreneurship has emerged more and more in the marketplace since the early 1980s, leading to entrepreneurial activity within companies and has emerged as a new theoretical insight (Forsström et al., 2015).

Along with bureaucratic intrusions into corporate culture to create an organizational commitment, corporate governance has increasingly attracted corporate executives in the 1960s and 1980s, so they 
can also invent and market their new products and services. With the onset of the 1980s and the sudden advances in the industry in the field of global competition, the importance of entrepreneurial processes in large corporations has been emphasized more than ever before, and researchers have focused on how entrepreneurship can be embedded in corporate governance structures (Abdullah et al., 2014).

Many companies today realize the need for corporate entrepreneurship, and in fact this shift in strategy is in response to the three needs imposed on corporations (Popescu and Simion, 2012). These three requirements include, first, the rapid growth of new competitors, the second, the distrust of traditional management practices in companies, and the third, the departure of the best workforce from companies and their pursuit of individual and independent entrepreneurship. Regarding the first need, this factor has accelerated in recent years and has challenged all companies and has even challenged many industries with advanced technologies. The pace of innovation and the introduction of new products have grown so rapidly that with these changes, initiatives and improvements have become commonplace in the markets. As a result, companies either have to innovate or they are doomed. On the second issue, that is, the distrust of traditional management practices in companies, it can be said that traditional management practices can no longer respond to rapid changes in the environment. Their incompatibility with decision-making conditions in such new environments has created a kind of mistrust of traditional management styles. The third issue and challenge are leaving the most qualified individuals in the companies to pursue independent entrepreneurship (Popescu and Simion, 2012).

The main reasons for encouraging people to leave their companies are the results of independent entrepreneurship such as economic and social well-being, reputation and independence in decision making. These factors will cause the young and experienced employees, more than in the past to encourage entrepreneurship. Because entrepreneurship will create a complex mental map that is associated with different mental maps for the future (Somers et al., 2014).

\section{ENTREPRENEURSHIP POLICY}

The Kurdistan Regional Government (KRG) needs to implement some policies in order to perform entrepreneurial activities. Policy is a multifaceted phenomenon and it is the decisions made by governments that define a goal and determine the means to achieve it, and decisions and policies are made by senior executives. Policies are tools to determine the general framework of managers' thinking to make better decisions. That can guide governments' thinking in purposeful decision making and thus ensure that decisions are made correctly (Foss et al., 2019).

In the last few decades, entrepreneurship policy (as part of macro policy) has also been rapidly evolving in various countries, first appearing in the United States (Hart, 2003) and then European policymakers quickly focused on it (Gilbert et al., 2004). Many policy makers and experts see entrepreneurship as the most important determinant of countries' long-term competitiveness. However, entrepreneurship is not well defined in the concept of research and policy. Focusing on entrepreneurship is sometimes considered synonymous with focusing on small and medium-sized enterprises (SMEs) and sometimes in other contexts, the concept of entrepreneurship is limited to young startups (Hölzl, 2010). Basically, entrepreneurship policy is related to the creation of an environment and support system that fosters the emergence of new entrepreneurs at the start-up stage and early stages of the growth of new companies. The Entrepreneurship Policy provides support services while encouraging people to become entrepreneurs. Governments also need to eliminate barriers to entry into the business world, provide opportunities to start a new business and stimulate entrepreneurial participation and investment (Tsai and Kuo, 2011).

Around the world, entrepreneurship is being increasingly supported by governments and their policies. For example, researchers claim that many governments have openly embraced the entrepreneurial 
economic theory. Entrepreneurship policy is nowadays implemented at the local, regional, national, and international levels (Hoppe, 2016). The EU pays particular attention to entrepreneurship policy and the 2020 Work Plan clearly demonstrates that entrepreneurship is an important growth factor in the future (Bager et al., 2015). Entrepreneurial human capital, such as industry experience and public education, enables entrepreneurs to discover and exploit entrepreneurial opportunities to succeed by increasing their capabilities (Zainol et al., 2018). Matlay and Hanon (2006) specifically argued that entrepreneurship development is currently the most important policy of governments. Stevenson and Lundström (2001) have considered entrepreneurship-related government policies, including the development of small and medium-sized enterprises, focusing on specific groups, the establishment of a new company, and a holistic policy.

In his study, So (1992) identified four categories of factors influencing policy implementation:

1. Policy factors (including type of policy, resources, policy incentives, degree of complexity, consistency and legitimacy, and clarity of policy).

2. Intervening factors (including communication and coordination, timing, implementation strategies, staff training, acceptance process, clear and continuous correlation and elimination of fear and uncertainty).

3. Environmental factors (including political support and socioeconomic, organizational climate context, organizational structure context and others support).

4. Executing factors (staff perception, staff competence and willingness).

In addition to summarizing the views of some experts, Winter (2012) has proposed a model, including: variables related to the policy formulation process, variables related to organizational and interagency implementation, variables related to bureaucratic behavior, variables related to response target group and community changes.

\section{PROSPECTS OF ENTREPRENEURSHIP DEVELOPMENT IN THE KURDISTAN REGION OF IRAQ}

The Kurdistan Region of Iraq (KRI) is determined to become one of the region's premier entrepreneurship centers in Iraq with the scientific expertise and potential of human resources, efficient technology, flexible structure, providing entrepreneurship education and promotion, consulting on technology development and the knowledge economy.

The economy of both the Kurdistan Region Government - KRG and the Government of Iraq - GOI are excessively driven by the public sector. $40 \%$ of Iraq's labor force at this time employed by the public sector, which is clearly higher than in more diversified economies in the region, such as Turkey $12 \%$, Iran 17\% and Jordan 31\% (Bartnick, 2017). Kurdistan has a population of about five to six million, of which only two million are in the working-age, and 1.4 million of them, which is about $70 \%$ of these working population is employed in the public sector (DeWeaver, 2015; Hussein, 2016). Publicsector employment can act as a factor against economic uncertainty and the unstable security environment and add value to places such as Kurdistan region and Iraq, which have been plagued by prolonged instability. However, the problems of over-dependence in the public sector employment have been exposed by the economic recession that has absorbed the region since 2014.

The Kurdistan Region of Iraq (KRI) has faced inestimable challenges as a result of its high unemployment rate at the beginning of 2013, while unemployment has increased sharply in this year, with $20 \%$ to $25 \%$ losing their jobs mostly in the private sector (Tasie, 2017). Furthermore, many factors have negatively affected economic growth, reducing private sector development. The first factor was fallen in global oil prices since 2014, another factor continuing budget disputes between Baghdad and Erbil, when the central government (Baghdad) cutting off the budget of KRG from the national budget in 2014 (DeWeaver, 2015; Sümer and Joseph, 2019). In addition, the war against the Islamic State in 
Iraq and al-Sham (ISIS), corruption, and poor governance, as well as the social reproduction of the risktaking mindset that promotes public sector employment (Sümer and Joseph, 2019).

The private sector should be reformed by both KRG and GOI, especially in focusing on entrepreneurship. Features in each region refer to social and physical foundations, labor force requirement and community organisms' effectiveness (Mihaela, 2016). Entrepreneurs, investors, and even businessmen are the particular greatest engine of the growth of the economy in the world. Entrepreneurship has a significant impact on sustainable economic development by creating employment, increasing GDP, reducing poverty and welfare of the whole society (Burke, 2011; Djukić, and Lepojević, 2015). At the same time, economic growth has had a major impact on entrepreneurial development (Sabella et al., 2014; Casares and Khan, 2016). In addition, the correlation between entrepreneurship and the growth of the economy might not be different in countries with different levels of development (Van Stel et al., 2005) as it can be seen in the Kurdistan region of Iraq.

The increasing share of SMEs (small and medium-sized enterprises) in some developing countries has led to changing economists' perceptions of economic growth drivers. SMEs create more than half of the jobs available worldwide and make the job opportunity more than twice the rate of established companies (Weinberger, 2016), these enterprises are driving innovation by generating new ideas, new products, and creating new businesses. The special importance of SMEs lies in the fact that they are very dynamic, fast-learning and prone to rapid change (Cuckovic and Bartlett, 2007) which enhances their competitiveness as well as the overall competitiveness of the economy (Ivanović-Djukić et al, 2018). Based on this idea, in 2017 the Iraq's Council of Ministers named the promotion of SMEs as one of the three pillars of its private sector development strategy by 2030. KRG and GOI have the opportunity to harness entrepreneurial power, and foster dramatic economic growth. But to take full advantage of the region's economic potential, there are a number of challenges that must first be addressed (Bartnick, 2017).

The basis of any entrepreneurial ecosystem is this mindset: Do aspiring entrepreneurs have the insight, appetite for risk, and resistance to pursuing their jobs? If this is the case, then there must be a set of structural situations in which entrepreneurs can operate (Matsunaga, 2019). The government must improve entrepreneurial infrastructures such as internet access and the banking system and create a lightweight regulatory system in which it would be easy to start entrepreneurship (Bartnick, 2017). They must also work with the private sector to ensure that successful entrepreneurs have access to the capital that they need to scale their business. Only after all these conditions have been met will the economy be in a position to take advantage of the valuable market opportunities that entrepreneurship can offer. The KRG and GOI are disproportionately dependent on public sector employment, which prevents the growth of the private sector needed for the KRG to come out from its recession.

Structural deficiencies in the entrepreneurship KRG and GOI ecosystems include insignificant burdens and lengthy procedures for creating new jobs, businesses and entrepreneurs, limited access to capital through banks and traditional investors, the lack of intellectual property protection, and unclear regulations on key growth areas such as e-business. Laws and regulations are not only the tools that put entrepreneurs back. They present the structure of business activities and adjust the parameters in which businesses and customers interact together. When this framework is completely lost, it creates an important uncertainty that impedes economic growth (Bartnick, 2017). The KRG wants to implement and enact laws that make the private sector more attractive, so the people of Kurdistan can take steps to develop a safe economy. It is time for the Kurdish population to become creative and entrepreneurial by starting small and medium-sized enterprises (SMEs) (Hussein, 2016), and agricultural and information technology industries would be ideal sectors for investment (Hilmi, 2018), and these could be achieved by emphasizing on; Creativity, Pragmatic ideation, Added value, Interdisciplinary work, Perseverance, Participatory and Competitiveness. 


\section{CHALLENGES OF ENTREPRENEURSHIP DEVELOPMENT}

Research on entrepreneurship policy also reveals a variety of factors such as development of training programs and consulting, infrastructure and financial support, research and development (Henrekson and Stenkula, 2010; Redford, 2012), entrepreneurship culture, intellectual property rights (Acs and Szerb, 2007; Audretsch, et al., 2007), creating entrepreneurial economics, empowering entrepreneurs and knowledge commercialization, access to external technologies and tax support and increasing entrepreneurial activities (Acs et al., 2014) providing economic, political, cultural and structural incentives, improving the environment, and accessing resources (Lundström and Stevenson, 2006).

Furthermore, formal organizational factors, namely government, finance, business and service infrastructure research and development policies. Informal organizational factors, such as social and cultural norms, skills development, business opportunities, social image (Alvarez et al., 2011). Entrepreneurs and entrepreneurship development in society, influence entrepreneurial practices (JafariMoghadam et al., 2017). Research by Kim et al, (2011) examined the effects of financial policy, labor force, and taxation on entrepreneurial activities. Lucky (2013) also explores the inefficiency of government policy on entrepreneurship in a study of the inefficiency of government policy in Nigeria, while noting the lack of proper implementation, and implementation of entrepreneurship policies as the main cause of instability in entrepreneurship policies.

In his research, Dennis (2011) has identified the institutions, cultures, competitiveness, and defined the benefits of competition, barriers and supports, policy goals, and direct or indirect actions in entrepreneurship development. Bennett (2014) In his research, focused on appropriate policies and policy tools for small businesses and young entrepreneurs in marketing, business creation, and finance. In a study, Bager et al., (2015) explored the role of the key interests of key decision-makers in shaping entrepreneurship policy at the national level. Mirzanti et al., (2015) also indicated that there are 12 government-run entrepreneurship programs aimed at increasing the number of entrepreneurs or startup. At the micro level, policies focus on business skills, identifying opportunities and psychological characteristics of individuals, including motivation. At the intermediate level, entrepreneurship is defined as an organization whose added value is through entrepreneurship process and business incentives and responsibilities; Acceptability, and lastly, the macro level include the effects of entrepreneurship on employment creation, business start-up, entrepreneurship culture, entrepreneurship infrastructure and education.

The findings of Agu and Ayogu (2015) research indicate that multiple taxes, lack of technology awareness and unfair competition are the challenges of entrepreneurship development in Nigeria. Technology improves entrepreneurship in Nigeria by improving customer satisfaction and reducing transaction time. In his study, Dhaliwal (2016) specifies that entrepreneurship brings new business ideas to life and creates jobs that facilitate personal growth, and with their innovative ideas, entrepreneurs can also solve social problems. In addition, in the study of Mehari and Belay (2017) it was found that factors such as access to communication media, education system reform, support for village-level associations have a positive impact on entrepreneurship development. The results also showed that age has a significant effect on one's desire for entrepreneurship. The literature suggests that entrepreneurial potential decreases with age. Moreover, the study of Ahmed (2018) concludes that, entrepreneurship and startups play an important role in promoting the state economy, and it also discusses the role of government in providing a favorable environment for enterprises' development.

\section{1 Challenges of Entrepreneurship Development in the Kurdistan Region of Iraq:}

According to the results of the research and the current situation in the Kurdistan region and Iraq, entrepreneurship development has the potential to play an active role in global markets, competitiveness, sustainable employment, development of justice, poverty reduction and community, government and public sector solutions. Entrepreneurial development in the Kurdistan region is also 
the most viable strategy to get out of the economic and social impasse that needs to be identified and overcome. Capacity building for entrepreneurship development requires entrepreneurial training and skills with a market-based approach based on the needs of society at all levels of education.

However, entrepreneurial development requires identifying and removing barriers and creating appropriate contexts for the development of productive activities and services. There is no doubt that a strong government presence in the Kurdistan region's economy and the obstacles to effective private competition and entrepreneurship make entrepreneurship development possible, but also impossible. It can be argued that entrepreneurs notice many challenges to their business before they can compete with the private sector for their activities. These challenges include three dimensions of anti-motivation, legal barriers, and the business environment:

\section{Anti-motivational factors of entrepreneurship}

- High financial risk (fear of losing personal capital)

- The main anti-motivation factor for entrepreneurship in KRG is that the profits from trade, manufacturing, and entrepreneurship activities are negligible compared to other economic activities such as imports of products.

- Lack of access to finance for investment, the inability to provide sufficient funds to start a business, and due to the financial crisis in recent years, very little capital is available to new entrepreneurs.

- The large volume of overseas brand advertising in all areas of the media and mass media makes the public's perception of Iraq's domestic product declined, so the bank's entrepreneurial status is motivated to start or continue its business. Creatively lose entrepreneurship and give up on the road.

- Administrative barriers and corruption in the public administration sector.

- Lack of skills (lack of proper and sufficient skills and experience in running a new business).

\section{Legal Barriers of entrepreneurship}

- Banking rules and regulations, lack of banking infrastructure in the Kurdistan region and cultural distrust of the banking system.

- Labor laws, lack of support of entrepreneurship.

- Companies registration laws, such as duration of registration, the expenditure of company registration, the complexity of related rules.

- Bankruptcy laws and regulations, the negative attitude of people towards failure in business.

- Trade and business laws, and regulations related to import and export.

- Tax regulations, the rate of tax on companies' income and complexity laws related to tax collection.

- Copyright rules and regulations, the lack of Intellectual Property (IP) rights and patent laws.

- Customs rules, regulations and tariffs.

\section{Business environment challenges}

Investigating the challenges and problems of entrepreneurship in the Kurdistan region of Iraq will not be complete without examining its business environment. According to top entrepreneurs, the failures of the business environment for new and growing companies are as follows:

- Lack of commercial, specialized infrastructure and the skills needed for new and growing companies.

- The lack of an entrepreneurial mindset and appropriate physical infrastructure for new and growing companies.

- Lack of support for social entrepreneurship and cultural norms, and lack of proper physical infrastructure for new and growing companies. 
- Lack of adequate financial support by providing access to capital and loans to new and growing companies.

- The lack or incompetence of government programs and policies to help new and growing companies.

- The Lack of emphasis on higher education programs and research on entrepreneurship development.

- Lack of intensive training programs focused on entrepreneurship and startup development.

- Improper transfer of government research and development results to new and growing companies.

- Lack of free-market space for new and growing companies.

\section{STRATEGIES OF REFORM AND REMOVING BARRIERS TO ENTREPRENEURSHIP DEVELOPMENT IN THE KURDISTAN REGION OF IRAQ}

According to the results obtained for removing the barriers to entrepreneurship development, the following suggestions are offered:

1. Review banking rules and regulations, such as reducing the requirements and legal procedures for providing banking facilities with appropriate bank interest rates for new and emerging enterprises.

2. Establishment and development of private banks specifically for the development of entrepreneurship and SMEs.

3. Modifying the labor law with the approach of entrepreneurship and sustainability of firms "neither work-oriented nor worker-oriented".

4. Modifying business, export, and import regulations by an entrepreneurial approach, and paving the way for e-commerce growth and development.

5. Reducing inappropriate administrative bureaucracy in public organizations, including municipalities, company registrations, industries and resources, customs and environmental management.

6. Establishing and developing office automation systems in government agencies and institutions to reduce costs and facilitate and eliminate unnecessary administrative procedures such as workflow procedures between departments, printing, copying, and other similar matters.

7. Developing Entrepreneurship education in public and private schools and universities, and opening advanced small business growth centers.

8. Development of science and technology of industrial settlements and business development centers and similar actions with an entrepreneurial approach.

9. Holding entrepreneurship and market innovation conferences in order to support innovation and promote ideas through professional entrepreneurs and investors.

10. Establishing an intellectual and financial support fund for entrepreneurs and business startups, and encourage their activities by offering access to financial help, loans, and capital.

11. Preventing excessive imports of foreign goods similar to domestic production to support domestic products and markets.

12. Establishing regular entrepreneurship consultation and business development centers with the private sector to better understand the limitations they face and how to deal with them, as well as encourage open dialogue between entrepreneurs and investors. 


\section{DISCUSSION AND CONCLUSION}

This article has attempted to extract and investigate various factors and challenges affecting entrepreneurship development from research conducted in this field. The results show that experts from different perspectives have looked at barriers to entrepreneurship development. In general, the results of the research on the obstacles and challenges of entrepreneurship development can be summarized in an overview:

Internal Barriers: These include motivational barriers. Improper efforts of the government and unspecified incentives for entrepreneurship development seem the first factor to have delayed the entrepreneurial development process in the Kurdistan region. Lack of easy access to capital and longterm finance for investment, as well as lack of good skills needed for starting and managing the business, and the absence of adequate training facilities and leadership development capacity for entrepreneurship activities are the challenges that entrepreneurs and startups have faced in this region.

Environmental barriers: The second category is the external barriers. The need to rethink and even redefine new concepts at the macro-level of policy-making are seen as essential strategies for reforming, removing these barriers, and creating the appropriate infrastructure for the development of organizational entrepreneurship. On the other hand, traditional strategies at the level of government agencies and development training centers are not capable of encouraging individuals to undertake entrepreneurial activities, also the traditional view of such organizations and centers are that the customer-oriented tendencies of the organization are not given sufficient attention in service delivery. Other barriers include the lack of proper connectivity tools, lack of regulation, lack of safety, and functional area barriers.

Outcome Barriers: The third category of entrepreneurship barriers is output barriers. Organizations need to change how they interact with other organizations and organs of society in order to confront the opportunities and threats that exist in today's world or are doomed. Like the other two barriers, there are significant obstacles that can accelerate the pace and speed of entrepreneurship in society. Some of the most important of these barriers are cultural-social barriers, the traditional definition of success, the ability to continue operating despite being ineffective, the frequent change of management over short periods of time.

Entrepreneurs and small businesses are the biggest drivers of private sector growth and developments in emerging markets around the world. It can be argued that both motivates and regulation factors as reviewed in this research could be the main challenges and barriers to entrepreneurship development in the Kurdistan region of Iraq. Entrepreneurs in the Kurdistan Region of Iraq face many challenges and barriers. So far, the evidence suggests that entrepreneurs have a long way to go before they can effectively drive economic change. There are people in every country who have an act of entrepreneurial courage and spirit, but that alone is not enough. Many conditions must be provided for the development of entrepreneurship in the country.

To encourage a positive spirit of entrepreneurship among young people as mentioned above in strategies of reform and removing barriers to entrepreneurship development, universities and other higher education institutions in the Kurdistan region need to be taken into consideration to focus more on business and be more entrepreneurial. They should be encouraged to develop more relationships with local businesses and to engage in additional business education at the universities and business development centers. Kurdistan region government should encourage and support entrepreneurship activities by offering bank facilities such as providing capital and long term loans to new and emerging enterprises. The government can also improve business laws with the entrepreneurship approach and seek to reform targeted legislative in areas of future growth such as e-commerce. The government can improve the entrepreneurial ecosystem by providing a free-market space that emphasizes emerging and 
growing companies. Along with that, the government by establishing private banks related to entrepreneurship can support small and medium-sized enterprises (SMEs).

\section{REFERENCES}

Abdullah, N. H., Shamsuddin, A., Wahab, E., \& Hamid, N. A. A. (2014). The relationship between organizational culture and product innovativeness. Procedia-Social and Behavioral Sciences, 129, 140147.

Abtahi, M., Karamipour, M., \& Abbasi, K. (2014). Investigating the effects of personal entrepreneurial characteristics. Management Science Letters, 4(3), 417-420.

Acs, Z. J., \& Szerb, L. (2007). Entrepreneurship, economic growth and public policy. Small business economics, 28(2-3), 109-122.

Acs, Z. J., Autio, E., \& Szerb, L. (2014). National systems of entrepreneurship: Measurement issues and policy implications. Research Policy, 43(3), 476-494.

Adenuga, R. A., \& Ayodele, K. O. (2013). Adolescents' entrepreneurial behaviour: The predictive effect of the big five personality factors. European Journal of Business and Social Sciences, 1(12), 48-58.

Agu, E., \& Ayogu, D. (2015). Assessing the Prospects and Problems of Entrepreneurship Development in Nigeria. International Journal of Business and Management Invention, 3(10), 208-221.

Ahmed, A. (2018). Promotion of Entrepreneurship Development and Start-Ups in Jammu and Kashmir. International Journal of Innovative Knowledge Concepts, 6(9), 07-13.

Alvarez, C., Urbano, D., Coduras, A., \& Ruiz-Navarro, J. (2011). Environmental conditions and entrepreneurial activity: a regional comparison in Spain. Journal of Small Business and Enterprise Development, 18(1), 120-140.

Audretsch, D. B., Grilo, I., \& Thurik, A. R. (2007). Explaining entrepreneurship and the role of policy: a framework. The handbook of research on entrepreneurship policy, 1-17.

Bager, T. E., Klyver, K., \& Nielsen, P. S. (2015). Special interest in decision making in entrepreneurship policy. Journal of Small Business and Enterprise Development, 22(4), 680-697.

Bartnick, A. (2017). Obstacles and Opportunities for Entrepreneurship in Iraq \& the Kurdistan Region. The Institute of Regional and International Studies (IRIS), the American University of Iraq-ulaimani, Kurdistan Region of Iraq.

Bennett, R. J. (2014). Entrepreneurship, small business and public policy: Evolution and revolution. Routledge.

Burke, A. (2011). The entrepreneurship enabling role of freelancers: Theory with evidence from the construction industry. International Review of Entrepreneurship, 9(3), 131-158.

Casares, M., \& Khan, H. (2016). Business dynamism and economic growth: US regional evidence. International Review of Entrepreneurship, 14(4): 423-446.

Cassim, S., Soni, P., \& Karodia, A. M. (2014). Entrepreneurship Policy in South Africa. Oman Chapter of Arabian Journal of Business and Management Review, 3(9), 29-43.

Cuckovic, N., \& Bartlett, W. (2007). Entrepreneurship and competitiveness: the Europeanisation of small and medium-sized enterprise policy in Croatia. Southeast European and Black Sea Studies, 7(1), 37-56.

Dennis Jr, W. J. (2011). Entrepreneurship, small business and public policy levers. Journal of Small Business Management, 49(1), 92-106.

DeWeaver, M. (2015). Kurdistan's Great Recession: From Boom to Bust in the Rentier Economy. IRIS Iraq Report. American University of Iraq-Sulaimani. December, 10.

Dhaliwal, A. (2016). Role of entrepreneurship in economic development. International Journal of scientific research and management, 4(6), 4262-4269.

Djukić, M. I., \& Lepojević, V. (2015). The effect of entrepreneurial activity on national competitivenes: A comparative analysis of developed and developing countries. Improving the Efficiency and Competitiveness of Enterprises and National Economies, pp. 169- 191.

Dovbiy, I. P., Mitrofanova, I. V., Russkova, E. G., Shkarupa, E. A., Batmanova, V. V., \& Mitrofanova, I. A. (2017). Tendencies, problems and prospects of the balanced and competitive Development of agrarian Entrepreneurship in Russia. Revista Galega de

Economia, 26(2), 97-112. 
Drucker, P. (2012). The discipline of innovation, selected articles, HBR innovation.

Forsström-Tuominen, H., Jussila, I., \& Kolhinen, J. (2015). Business school students' social construction of entrepreneurship: Claiming space for collective entrepreneurship discourses. Scandinavian Journal of Management, 31(1), 102-120.

Foss, L., Henry, C., Ahl, H., \& Mikalsen, G. H. (2019). Women's entrepreneurship policy research: a 30-year review of the evidence. Small Business Economics, 53(2), 409-429.

Gilbert, B. A., Audretsch, D. B., \& McDougall, P. P. (2004). The emergence of entrepreneurship policy. Small Business Economics, 22(3-4), 313-323.

Hart, D. M. (Ed.). (2003). The emergence of entrepreneurship policy: governance, start-ups, and growth in the US knowledge economy. Cambridge University Press.

Henderson, J., \& Weiler, S. (2010). Entrepreneurs and job growth: probing the boundaries of time and space. Economic Development Quarterly, 24(1), 23-32.

Hilmi, M. (2018). Entrepreneurship in farming: What is the current status of knowledge in the Kurdistan Region of Iraq?. Middle East J, 7(3), 858-875.

Hölzl, W. (2010). The economics of entrepreneurship policy: introduction to the special issue. Journal of Industry, Competition and Trade, 10(3-4), 187-197.

Hoppe, M. (2016). Policy and entrepreneurship education. Small Business Economics, 46(1), 13-29.

Hussein, B. (2016). It's Time for Iraq's Kurds to be Entrepreneurial. Atlantic Council. https://www.atlanticcouncil.org/blogs/new-atlanticist/it-s-time-for-iraq-s-kurds-to-be entrepreneurial/

Ivanović-Djukić, M., Lepojević, V., Stefanović, S., van Stel, A., \& Petrović, J. (2018). Contribution of Entrepreneurship to Economic Growth: A Comparative Analysis of South-East Transition and Developed European Countries. International Review of Entrepreneurship, 16(2), 257-276.

Jafari-Moghadam, S., Zali, M., \& Sanaeepour, H. (2017). Tourism entrepreneurship policy: a hybrid MCDM model combining DEMATEL and ANP (DANP). Decision Science Letters, 6(3), 233-250.

Kim, Y., Kim, W., \& Yang, T. (2010). The effect of public policy on entrepreneurial activity: Evidence from OECD countries. In ICSB World Conference Proceedings (p. 1). International Council for Small Business (ICSB).

Knight, F.H. (1921) Risk, Uncertainty and Profit. Boston: Houghton Mifflin.

Liñán, F., \& Chen, Y.W. (2009). Development and cross-cultural application of a specific instrument to measure entrepreneurial intentions. Entrepreneurship Theory and Practice,33(3), 593-617.

Lucky, E. O. I. (2013). Exploring the ineffectiveness of government policy on entrepreneurship in Nigeria. International Journal of Entrepreneurship and Small Business, 19(4), 471-487.

Lundstrom, A., \& Stevenson, L. A. (2006). Entrepreneurship policy: Theory and practice (Vol. 9). Springer Science \& Business Media, 117-152.

Mathew, V. (2010). Women entrepreneurship in Middle East: Understanding barriers and use of ICT for entrepreneurship development. International Entrepreneurship and Management Journal, 6(2), 163181.

Matlay, H., \& Hannon, P. D. (2006). Teaching pigeons to dance: sense and meaning in entrepreneurship education. Education Training, 48(5), 296-308.

Matsunaga, H. (2019). The Reconstruction of Iraq after 2003: Learning from Its Successes and Failures. World Bank Publications, The World Bank Group, 1818 H Street NW, Washington, USA.

McClelland, D. C. (1987). Characteristics of successful entrepreneurs. The journal of creative behavior, 21(3), 219-233.

Mehari, A. T., \& Belay, C. F. (2017). Challenges and prospects of entrepreneurship development and job creation for youth unemployed: evidence from Addis Ababa and Dire Dawa city administrations, Ethiopia. Journal of Innovation and Entrepreneurship, 6(11), 1-22.

Mihaela, S. (2016). Competitiveness and economic growth in Romanian regions. Journal of Competitiveness, 8(4), 46-60.

Mirzanti, I. R., Simatupang, T. M., \& Larso, D. (2015). Mapping on entrepreneurship policy in Indonesia. Procedia-Social and Behavioral Sciences, 169, 346-353.

Montoro-Sánchez, Á., Soriano, D. R., \& Knörr, H. (2011). From top management to entrepreneurship: women's next move?. International Journal of Manpower. 32(1), 99-116. 
Muro, C. T., Sanchez, J. R. V., \& Castell, F. F. (2013). Entrepreneurship in Latin America during the 21st century. European Scientific Institute, ESI (publishing), 273.

Niyazi, M. (2008). Sociological analysis of the factors affecting university women's entrepreneurship. Economy, Business and Society, 102: 6-57.

Nkechi, A., Emeh Ikechukwu, E. J., \& Okechukwu, U. F. (2012). Entrepreneurship development and employment generation in Nigeria: Problems and prospects. Universal Journal of Education and General Studies, 1(4), 88-102.

Popescu, C. A., \& Simion, P. C. (2012). Entrepreneurship Education and e-learning: A Perfect Match. Journal of Electrical and Electronics Engineering, 5(1), 203.

Rabiei, A., \& Nazarian, Z. (2013). Studying the Obstacles of Entrepreneurship among Iranian Educated Women. Innovation and Creativity in the Humanities, 2(4), 1-26.

Redford, D. T. (2012). Entrepreneurship and Public Policy in Today and Tomorrow's Portuguese republic. University of California.

Sabella, A. R., Farraj, W. A., Burbar, M., \& Qaimary, D. (2014). Entrepreneurship and economic growth in West Bank, Palestine. Journal of Developmental Entrepreneurship, 19(01), (1450003) 1- 15.

Samitowska, W. (2011). Barriers to the development of entrepreneurship demonstrated by micro, small and medium enterprises in Poland. Economics \& Sociology, 4(2), 42-49.

So, H. (1992). Factors affecting the implementation of democratic school management policy in the Republic of Korea.

Somers, M. J., Passerini, K., Parhankangas, A., \& Casal, J. (2014). Using mind maps to study how business school students and faculty organize and apply general business knowledge. The International Journal of Management Education, 12(1), 1-13.

Stevenson, L., \& Lundström, A. (2001). Patterns and trends in entrepreneurship/SME policy and practice in ten economies (Vol. 3). Vällingby: Elanders Gotab.

Sümer, F., \& Joseph, J. (2019). Compatibility of the Kurdistan Region of Iraq's Institutions and Economic Development Within Iraq. In Iraqi Kurdistan's Statehood Aspirations (pp. 27-54). Middle East Today. Palgrave Macmillan, Cham.

Tasie, G. O. (2017). The Symbiosis between Entrepreneurship Formation and Employment Creation: A Strategy for Job Opportunities in Kurdistan Region. International Journal of Academic Research in Business and Social Sciences, 7(3), 33-46.

Tsai, W. H., \& Kuo, H. C. (2011). Entrepreneurship policy evaluation and decision analysis for SMEs. Expert Systems with Applications, 38(7), 8343-8351.

Van Stel, A., Carree, M., \& Thurik, R. (2005). The effect of entrepreneurial activity on national economic growth. Small business economics, 24(3), 311-321.

Weinberger, M. (2016). Why entrepreneurs are essential to the global economy-EY. Financial Times, June, 7 .

Wibowo, A., \& Saptono, A. (2018). Does teachers' creativity impact on vocational students' entrepreneurial intention?. Journal of Entrepreneurship Education, 21(3), 1-12.

Winter, S. C. (2012). Implementation perspectives: Status and reconsideration. The Sage handbook of public administration, 265-278.

Zainol, N. R., Al Mamun, A., Ahmad, G. B., \& Simpong, D. B. (2018). Human Capital and Entrepreneurial Ompetencies towards Performance of Informal Microenterprises in Kelantan, Malaysia. Economics \& Sociology, 11(4), 31-50. 